\title{
Waqf (Endowment) Practice in Malaysian Society
}

\author{
NUR KHALIDAH DAHLAN*, NOOR INAYAH YAA'KUB, MOHAMAD ABDUL HAMID \& \\ MOHD RIZAL PALIL ${ }^{1}$
}

\begin{abstract}
Justice and equality are not identical in the sense that under certain circumstances, justice may only be achieved through inequality or unequal distribution of wealth. The two aspects of justice, which are corrective justice and distributive justice in this definition both comprehend of justice as a social concept as it incorporates social relations and would have little meaning if it were to apply to an individual in total isolation from society. Thus by comparing the pertinent literature on jurisdiction of the courts in terms of waqf and judicial decisions, this article seeks to describe the pros and cons of waqf practices and how it reflects justice to the Malaysian society.
\end{abstract}

Keywords: waqf, fatawa, mutawalli, justice.

According to Syed Ameer Ali (1976), waqf is defined as dedicating a certain property to Allah SWT and devoting it for a religious cause for the benefit of human beings. The history of waqf is traced back to the time of the Prophet SAW himself as the companions of the Prophet SAW were also practising the waqf of properties. In Islamic term, waqf is defined as the perpetual dedication of any property from which its benefit may be used for any charitable purpose, whether as general waqf (-any waqf that is created for a general charitable purpose according to Syarak-Islamic Law) or special waqf (-a waqf that is created for a specified charitable purpose according to Syarak) according to Syarak, ruling of Islamic law. The definition also being accepted by the state law, and is referred to as Waqf Enactment of Selangor State (Enactmen Waqf state of Selangor, No. 7, 1999). Although waqf has been practiced by the Malaysian Muslims since the early 1887, it is still unfamiliar among the Malaysian non-Muslims. Therefore, this paper seeks to describe and examine the development of courts and states' jurisdiction on waqf and how justice is reflected in the concept of waqf in Malaysia. This paper is divided into four sections. Section 1 provides an overview of jurisdiction to hear waqf related cases in Malaysia. Section 2 clarifies the fatawa regarding waqf in Malaysia. Section 3 is dedicated to describing the roles of a mutawalli and its relation in achieving justice. Lastly, Section 4 provides a conclusion for this paper.

\section{The Overview of Jurisdiction to Hear Waqf}

There is no provision either in the Federal Constitution or in the Court of Judicature Act 1964 which confers the civil courts the jurisdiction to decide Waqf related cases. However, in the laws of Malaysian states, waqf is regarded as a type of trust by Shariff Judge as in Ashabee \& Ors v.

\footnotetext{
${ }^{1}$ Nur Khalidah Dahlan *(Corresponding author), Postgraduate Student at Institute of Malaysian and International Studies (IKMAS), Universiti Kebangsaan Malaysia, 43600 BANGI, Selangor, Malaysia, email: nkhalidahd@gmail.com; Noor Inayah Yaa'kub, Ph.D., Professor at Faculty of Economic \& Management, Universiti Kebangsaan Malaysia, 43600 BANGI, Selangor, Malaysia, email: inayah@ukm.my; Mohamad Abdul Hamid, Ph.D., Assoc. Prof. at Faculty of Economic \& Management, Universiti Kebangsaan Malaysia, 43600 BANGI, Selangor, Malaysia, email: mdah@ukm.my; Mohd Rizal Palil, Ph.D., Lecturer at Faculty of Economic \& Management, Universiti Kebangsaan Malaysia, 43600 BANGI, Selangor, Malaysia, email: mr_palil@ukm.my.
} 
Mahomed Hashim \& Anor (1887: 4 Ky 213) which finding remains intact for the next 100 years (See in Haji Embong bin Lain-Lain v. Tengku Maimunah (1980: MLJ 286), Re Dato Bentara Luar (1982: MLJ 264), Majlis Agama Islam Pulau Pinang v. Isa Abdul Rahman \& Anor [1992: 2 MLJ 244, G Rethinasamy v. Majlis Ugama Islam, Pulau Pinang \& Anor (1993: 2 MLJ 166), Shaik Zolkaffily bin Shaik Natar \& Ors (sued as trustees of the estate of Sheik Eusoff bin Sheik Latiff, deceased) v. Majlis Agama Islam Pulau Pinang dan Seberang Perai (1997: 3 MLJ 281) and in Barkath Ali bin Abu Backer v. Anwar Kabir bin Abu Backer \& Ors (1997: 4 MLJ 389).

As waqf is regarded as a trust, then it is subject to the Trustee Act 1949. According to this case, the act is specified and recognised, by virtues of section 2, only by the High Courts of Malaya and Borneo hence, have the jurisdiction to try and decide on trust cases. The jurisdiction of the Syariah Court is thus excluded. Therefore, based on this provision, according to Ahmad Ibrahim, waqf falls within the jurisdiction of the civil courts and not the Syariah Courts (Ahmad Ibrahim 1993). Nevertheless, there are some decided cases to the effect of which Waqf can fall within the jurisdiction of the civil courts. For examples, in the cases of Shaik Zolkaffily bin Shaik Natar \& Ors (sued as trustees of the estate of Sheik Eusoff bin Sheik Latiff, Deceased) (1997: 3 MLJ 281), G Rethinasamy (1993: 2 MLJ 166), and Isa Abdul Rahman (1992: 2 MLJ 244).

It should be noted that, certain federal statutes embodies, the fact that civil law or the principles of English law shall not be applicable to waqf. Thus, the civil laws are negated from having any impact on waqf in terms of application. This is made into effect pursuant to section 4(2)(e) of the National Land Code 1965 (NLC), which spells out that nothing in the NLC shall affect laws relating to waqf. Based on this provision, NLC cannot overrule laws relating to waqf. Instead, the law applicable to waqf is the law 'for the time being in force'. It is submitted that Waqf land is under the scope of Islamic law. This is shown in the case of Pesuruhjaya Hal Ehwal Agama dan Lain-Lain v. Tengku Mariam (1970: 2 MLJ, 222), in which it was submitted that the law 'for the time being in force' was Terengganu Administration of Islamic Law Enactment 1955. Yet, it was held not applicable. Instead, the court referred to Privy Council decisions on cases from India. However, in the Federal Court, this decision was overruled, based on a different reason, the parties had subjected themselves to following the fatwa of the local Mufti. In Malaysia, however, the establishment and jurisdiction of the Syariah Court are the concerns of the respective states. The respective states are responsible to make laws relating to matters that fall within the List II of the $9^{\text {th }}$ Schedule to the Federal Constitution (FC). The State list, that is List II (1) of the Ninth Schedule to the FC, as regards waqf, reads as follows:

Except with respect to the Federal Territories of Kuala Lumpur and Labuan, Islamic law and personal ... Waqf and the definition and regulation of charitable and religious trusts, the appointment of trustees and the incorporation of persons in respect of Islamic religious and charitable endowments, institutions, trusts, charities and charitable institutions operating wholly within the State...

In summary, waqf is considered as one of the State matters. The jurisdiction of the respective State Syariah Courts is to be found in each state administration of Islamic affairs enactments. The earliest case on waqf was Koh Cheng Seah Administrator of the Estate of Tan Hiok Nee, Decd. v. Syed Hassan \& Anor (1930: 1 MC 180). The issue in this case was the English common law rule against perpetuities was not part of the law of the State of Johore, and accordingly the deed of waqf was not invalid as being against public policy. However, the court held that the English common law rule against perpetuities was not part of the law of the State of Johore and accordingly the waqf was valid, according to Waqf Enactment 1911, Section 4:

... if at any time prior to the commencement of the enactment any land should have been declared to be tanah wakaf other than for some public or charitable purpose, the ownership thereof shall, as from the commencement of this enactment, be deemed to 
vest exclusively in the person or persons beneficially entitled to the rents and profits thereof.

It can be observed that this enactment does not declare such a waqf to be void, but confirms the waqf and bestows the beneficial interest upon the persons entitled to the rents and profits, which would appear to suggest that the legislature does not regard such waqf as invalid. However, if the parties involved are non-Muslim, the Syariah Court will have no jurisdiction to hear and determine all actions and proceedings concerning waqf. This decision was made in the case of Tengku Zainul Akmal bin Tengku Besar Mahmud \& Anor v. Majlis Agama Islam dan Adat Melayu Terengganu \& Anor (2012: 3 SHLR 39).

\section{Fatawa on Waqf Matters in Malaysia}

Basically, every decision or ruling relating to Islam is seen as the sole authority of the States. It is placed under a body known as the National Council for Fatwa Committee of Islamic Religious Affairs Malaysia (Jawatankuasa Fatwa Majlis Kebangsaan Bagi Hal Ehwal Agama Islam Malaysia). At the state level, institutional fatwa is a legal entity other than the State Islamic Religious Council, State Islamic Religious Department, and Syariah Court granted recognition by each state's Islamic law (Nooh 2003). The problems and disputes arising in respect of Waqf property involving Islamic law will be referred to the Fatwa Committee Meeting and the committee itself will address these problems (Mahmood Zuhdi 2004). Laws enacted in the states have delegated authority to the respective state governments to set up a committee to help the department to issue a fatwa of Mufti Council (Suwaid Tapah 2004).

\section{Fatwa on Waqf (Land Acquisition) by State Authorities}

Even though the waqf lands are donated by an individual or a group for the purpose of charity, some issues arise when a waqf land is given to the authorities. In this issue, the National Council for fatwa (Muzakarah Jawatankuasa Fatwa kali ke-46) had decided that:

a. Waqf land shall not be transferred at all except when an emergency requires so with certain conditions.

b. Waqf land that had been transferred to the government, shall be compensated according to the value of the land or replaced by other land that have equal or better value.

c. Waqf land that will undergo development for the construction of public facilities such as roads, drainage, and electricity substation site and so on, shall be exempt from giving up to the authorities.

d. For special waqf land that have specific purposes such as mosques, schools and others, any parties that will take the land shall allocate certain parts of waqf land as a substitute waqf land. The substitute waqf land must have the similar or better value as the original waqf land. For example, if a multi-story building is built, a certain number of units of the building must be of equal value to mosques, schools and so on, as intended by waqif.

To recapitulate, this fatawa shows that basically the waqf or donated land will not be taken by the authority without reasonable grounds. The authorities shall only be permitted to take the land if it is bound by the conditions contained in the legislation. However, if the situation is considered critical and there is no other option, then there will be an amendment on the legislation concerning land acquisition (waqf). In addition to that, the authorities also have given the option of whether to replace it with a value of monetary compensation or replace it with another land that has similar value or better with respect to the conditions contained in 
the concept of waqf. Consequently, the State Fatwa Committee or the Board shall be responsible to issue a fatwa that is accommodative to the current needs of the society. Fatwa issued shall be coordinated at the state and national levels. Every fatwa must have a firm stand that the lands should not be taken by the authorities for private development purposes.

\section{The Roles of a Mutawalli}

In Malaysian context, the administrator of waqf is under the power of the respective State Religious Councils which having their own departments and units carry out the administration of the waqf property for the benefits of the beneficiaries named in the waqf. If no beneficiaries are stated, it will be determined by the Islamic jurists based on the injunction of the al-Quran and traditions of the Prophet Muhammad PBUH. In modern practice for the management of waqf properties, a trustee from a government institution will be appointed. The trustee is called a mutawalli or nazir.

A mutawalli is an individual who is appointed by the wakif, founder of the waqf, a person who gives up ownership of a certain asset in favour of the public, to administer it in generally beneficial manner to the poor and the needy. A religious cause for which a waqf is created is not necessarily confined only to mosques and cemeteries. It can also be used to finance and sustain mosques, schools, hospitals, and other charitable institutions in the fields of education, healthcare, and even infrastructural works such as road, water canals, and bridges. The appointment process of a mutawalli will be conducted in the light of the administration of waqf based on the terms of the waqf deed that usually include a provision for the appointment of an administrator or a mutawalli. Classical fiqh rules state that the power to appoint the mutawalli is primarily within the jurisdiction of the founder of the waqf (waqif). The waqif could also choose an individual known for his trustworthiness as a mutawalli to manage the Waqf property for the benefit of the beneficiaries. After the founder's death, the office of the manager would go to the person appointed by him. In the absence of such an appointment, the Syariah Court will appoint a mutawalli for managing the waqf.

The main role of a mutawalli is to manage the waqf property in accordance with the terms and conditions laid down by the waqif. The mutawalli is under the obligation to carry out the instructions of the waqif and to safeguard and protect the waqf property and its revenue. He is responsible to maintain the waqf property, ensure that it is in good condition, collect its revenues, and distribute them to the beneficiaries. He is also responsible for the maintenance, management, and development of the waqf property. He has no right to sell, exchange, or mortgage the Waqf property or borrow money in order to spend on waqf without the permission of the court.

Nonetheless, the practice could lead to the mismanagement of waqf properties and denial of the beneficiaries' due rights assigned to them in the original waqf declaration as the criteria of appointing a mutawalli are based on good traits rather than based on his managerial and developmental skills. Subsequently, this practice has a discouraging effect on the creation of Waqf made for the general welfare of the poor and the needy (Saleem 2010). An institution is always a better choice than an individual mutawalli. The waqf properties will benefit greatly from the teamwork, expertise, and professional management that institutional mutawalli could offer. With the availability of the institution as a mutawalli, Muslims will have a variety of choices for the creation and dedication of their waqf properties and they could appoint an institution of their choice as a mutawalli for their waqf. The Federal Government or the states should also create awareness and promote the creation of waqf as a whole in favour of educational and welfare activities.

As a conclusion, the Islamic philanthropic practice of waqf bears significance to human wellbeing across generations. The spirit behind waqf is that contributions to the public good should be made in a durable form for instances land, infrastructure, or a particular service that 
will not only serve the immediate needs of the present generation but also the future generations as well (Tadros 2012). In addition to that, due to the improvements made by the legal institution, their roles and functions would co-exist and support each other on Waqf. This is to enable them to function effectively in today's changed circumstances. As it did throughout the Islamic history, waqf plays an important role in socio-economic development such as in the fields of education, healthcare, and other welfare activities, The ideological basis for Islamic philanthropy is bound by a concept of wellbeing that encompasses relations between individuals in a community, the outreach of a Muslim community to another, and the relationship between the individual and God. As briefly put by Alterman \& Hunter (2004), in Muslim's conceptions of faith and community, humans are linked to each other through their obligations to God.

A charitable act is therefore neither merely an act of faith nor merely an act of community. It is the building of community through faith, and the building of faith through the deepening of community. In this structure, charity is not so much an act of virtue as it is one of obligation. All in all, waqf is the permanent dedication, by a Muslim, of any property for any purpose recognised by Islamic law as religious, pious, or charitable. Waqf causes the transfer of ownership, of the thing dedicated, to God. Its profits are devoted or applied to the benefit of mankind. Islam lays great emphasis on supporting the poor. The Quran and Sunah declare in clear word that it is the responsibility of the wealthy to look after the poor sections of society (without considering what race or religion they are).

\section{References}

Ahmad Hidayat Buang. 2004. Fatwa di Malaysia (Fatwas in Malaysia). Kuala Lumpur: Jabatan Syariah dan Undang-undang Universiti Malaya.

Ahmad Ibrahim. 1993. The future of the shariah and the shariah courts in Malaysia. Journal of Malaysian and Comparative Law 20.

Alterman, J., \& S. Hunter. 2004. The idea of philanthropy in Muslim contexts. Washington DC: The Centre for Strategic and International Studies.

Ismail Omar. 2011. Tanah oh tanah. Skudai: Muapakat Jaya Percitakan Sdn. Bhd.

K.y-Kyshe's Reports (Law Reports Date 1808-1890).

Mahmood Zuhdi Hj. Ab Majid. 2004. Fatwa dan ssu semasa: Masalah dan Cabaran di Malaysia. Jurnal Syariah 12(2).

M.C -Malayan Cases (Mallal's Digest Case date 1930-2003).

MLJ -Malayan Law Journal Reports. 1997: 3 MLJ 281, 1993: 2 MLJ 166, 1992: 2 MLJ 244, 1970: 2 MLJ, 222.

Mohammad Hashim Kamali. 1999. Freedom, equality and justice in Islam. Islamic Texts Society.

Mohd Afendi Bin Mat Rani. 2008. Fatwa wakaf di Malaysia: Analisis khusus fatwa pengambilan tanah wakaf oleh pihak berkuasa negeri. Konvensyen Kebangsaan Pengurusan Harta Pusaka, Wasiat dan Wakaf. Terengganu.

Saleem, Muhammad Yusuf. 2010. Mutawalli institutions for the management of waqf properties. Malaysia Law Journal 4( MLJ cxiv).

Nooh Gadut. 2003. Kedudukan dan peranan fatwa dalam pelaksanaan undang-undang syariah di Malaysia. In Seminar Perundangan Syariah ke Arah Mewujudkan Kerangka Perundangan Islam yang Lebih Lengkap dalam Sebuah Negara Islam: Kes Malaysia. Institut Kefahaman Islam Malaysia (IKIM) \& Jabatan Mufti Negeri Selangor.

Salleh Buang. 2002. Malaysian legal history: Cases and materials. Kuala Lumpur: Dewan Bahasa dan Pustaka.

S.H.L.R-Shariah Law Reports.

Suwaid Tapah. 2004. Perundangan dan penguatkuasaan fatwa. In Fatwa di Malaysia. Kuala Lumpur: Jabatan Syariah dan Undang-undang Universiti Malaya. 
Syed Abdul Kader, Sharifah Zubaidah Md Dahlan \& Nuarrual Hilal. 2009. Current legal issues concerning waqf in Malaysia. International Conference on Waqf Laws \& Management: Reality and Prospects. International Islamic University Malaysia, Gombak.

Syed Ameer Ali. 1976. The law relating to gifts, wakfs, wills, pre-wmption and bailment. n.p.: Law Publishing Company.

Tadros, Mariz. 2012. Islamic philanthropy, development and wellbeing. In Commissioned Paper, The Bellagio Initiative: The future of philanthropy and development in the pursuit of human wellbeing.

The Ruling on the Transfer of Part of Waqf Land to the Authority. The 46th Muzakarah (Conference) of the Fatwa Committee of the National Council for Islamic Religious Affairs Malaysia held on 22nd April 1999. http://www.e-fatwa.gov.my/fatwakebangsaan/hukum-menyerahkan-sebahagian-tanah-wakaf-kepada-pihak-berkuasa. 